\title{
Pyruvate Carboxylase in Rhodopseudomonas spheroides
}

\author{
By J. PAYNE AND J. G. MORRIS \\ Department of Biochemistry, School of Biology, University of Leicester, \\ Leicester LEI 7 RH
}

(Accepted for publication 7 August 1969)

\begin{abstract}
SUMMARY
Unlike some other photosynthetic bacteria, Rhodopseudomonas spheroides directly carboxylates pyruvate in a reaction catalysed by a pyruvate carboxylase (E.C. 6.4.I.I). A partially purified preparation of the enzyme was acetylCoA-dependent. No phosphoenolpyruvate synthetase or phosphoenolpyruvate carboxylase activity was detected in extracts of $R$. spheroides. The organisms dependence upon its pyruvate carboxylase was shown by the fact that a mutant strain which lacked this enzyme was unable to grow either anaerobically in the light, or aerobically in the dark, on glucose or pyruvate (with $\mathrm{CO}_{2}$ ). Convenient spectrophotometric assays for pyruvate carboxylase are reported.
\end{abstract}

\section{INTRODUCTION}

A number of photosynthetic bacteria, including Chlorobium thiosulphatophilum, a Chromatium sp., and Rhodospirillum rubrum, convert pyruvate indirectly to oxaloacetate by the sequential action of phosphoenolpyruvate synthetase (Cooper \& Kornberg, 1967) and phosphoenolpyruvate carboxylase (E.C. 4.I.I.3I). These enzymes have been implicated in a reductive carboxylic acid cycle which could accomplish the net synthesis of oxaloacetate from carbon dioxide during photoautotrophic growth of these organisms and might play a special role in their photoproduction of amino acids (Evans, Buchanan \& Arnon, 1966; Buchanan, Evans \& Arnon, 1967).

In this paper we report that neither phosphoenolpyruvate synthetase nor phosphoenolpyruvate carboxylase was detected in cell extracts of Rhodopseudomonas spheroides. This organism directly carboxylates pyruvate in a reaction catalysed by a pyruvate carboxylase (E.C. 6.4 I. I) which appears to be acetylCoA-dependent.

\section{METHODS}

Organism. Rhodopseudomonas spheroides NCIB 8287 was grown in stab culture, anaerobically in the light at $32^{\circ}$, using malate plus glutamate medium S of Lascelles (I956) supplemented with $0 \cdot 1 \%$ yeast extract (Oxoid) and solidified with agar. The organism was subcultured monthly and maintained at room temperature.

The pyruvate carboxylase-less mutant strain $R$. spheroides $p y c^{-}$was derived from the above organism by ultraviolet irradiation of cells grown aerobically in the dark on lactate medium. Following enrichment of potential mutants by penicillin treatment of the irradiated organisms (during continued aerobic incubation in lactate medium), survivors were replica plated on selective media. Those colonies were isolated which grew on lactate plus malate plates but which were incapable of growth on either lactate 
or pyruvate as sole carbon source. Pure cultures derived from these colonies and grown in lactate plus malate liquid medium, were screened for their content of pyruvate carboxylase. The strain finally selected, $R$. spheroides $p y c^{-}$, was completely devoid of any pyruvate carboxylase activity.

Growth media. A defined, liquid medium was used which contained, per $1 .: \mathrm{Na}_{2} \mathrm{HPO}_{4}$, 0.77 g.; $\mathrm{KH}_{2} \mathrm{PO}_{4}, 0.35$ g.; $\mathrm{NH}_{4} \mathrm{Cl}, 3.2 \mathrm{~g}$.; $\mathrm{MgSO}_{4} .7 \mathrm{H}_{2} \mathrm{O}$, 0.12 g.; nitrilotriacetic acid, 0.04 g.; $\mathrm{CaCl}_{2} .6 \mathrm{H}_{2} \mathrm{O}, 0.02 \mathrm{~g}$.; $\mathrm{FeSO}_{4} \cdot 7 \mathrm{H}_{2} \mathrm{O}, 0.4 \mathrm{mg}$.; ammonium molybdate. $4 \mathrm{H}_{2} \mathrm{O}$, 0.05 mg.; 'Metals 44' (Cohen-Bazire, Sistrom \& Stanier, 1957), 0.2 ml., and chosen carbon sources at suitable final concentration(s). After sterilizing by autoclaving at I $5 \mathrm{lb}$./in. ${ }^{2}$ for $15 \mathrm{~min}$., the following additions were made aseptically from membranefiltered solutions, per 1. : nicotinic acid, $0.2 \mathrm{mg}$; thiamine. $\mathrm{HCl}, 0.1 \mathrm{mg}$; biotin, $0.02 \mathrm{mg}$.

Photosynthetic growth. I 1. cultures in Roux bottles, inoculated from stab cultures (above), were continuously sparged with $95 \% \mathrm{~N}_{2}$ plus $5 \% \mathrm{CO}_{2}(\mathrm{v} / \mathrm{v})$ and incubated in light ( $700 \mathrm{ft}$ candles) at $32^{\circ}$.

Aerobic growth in the dark. I 1. cultures in 21 . Erlenmeyer flasks were reciprocally shaken at $30^{\circ}$. When acetate was the main carbon source, $\mathrm{NaHCO}_{3}(0.5 \mathrm{~g}$./1.) was aseptically added from a membrane-filtered solution immediately before inoculation from aerobic slope cultures on the growth medium solidified with $\mathrm{I} \cdot 5 \%$ agar.

Preparation of extracts. Organisms were harvested in the midexponential phase of growth by centrifuging at $17,000 \mathrm{~g}$ for $10 \mathrm{~min}$. at $2^{\circ}$. They were washed in $0.0 \mathrm{I} \mathrm{M}$-tris$\mathrm{HCl}$ buffer $\mathrm{pH} 7 \cdot 7$ and resuspended to 15 to $20 \mathrm{mg}$. dry $\mathrm{wt} / \mathrm{ml}$. in this buffer supplemented with $0.2 \mathrm{M}-\mathrm{KCl}$. After ultrasonic treatment usually for $3 \mathrm{~min}$. at $<5^{\circ}$, using a I00 $\mathrm{W}$ M.S.E. ultrasonic disintegrator, unbroken organisms and cell debris were removed by centrifuging at $25,000 \mathrm{~g}$ usually for $15 \mathrm{~min}$. at $2^{\circ}$.

Estimation of protein. Soluble protein was measured by the method of Lowry, Rosebrough, Farr \& Randall (195I).

Enzyme assays. All spectrophotometric assays were performed at room temperature in silica cuvettes ( $1.5 \mathrm{ml}$.; I cm. light path) with a Unicam SP800 spectrophotometer.

Phosphoenolpyruvate synthetase. This enzyme was assayed (a) by measuring the initial rate of ATP-dependent pyruvate utilization, as described by Cooper \& Kornberg (1967, 1969); $(b)$ by measuring the rate of production of phosphoenolpyruvate from ATP plus pyruvate using the procedure described by Buchanan \& Evans (1966).

Phosphoenolpyruvate carboxylase. This enzyme was assayed spectrophotometrically using $(a)$ the citrate synthase-coupled assay procedure for pyruvate carboxylase (below), but omitting ATP and replacing pyruvate with 10 $\mu$ mole phosphoenolpyruvate; $(b)$ the malate dehydrogenase-coupled system described by Canovas \& Kornberg (1969).

Pyruvate carboxylase. This enzyme was assayed spectrophotometrically by two methods:

(a) A citrate synthase-coupled assay. Oxaloacetate formed by the action of pyruvate carboxylase, in the presence of excess citrate synthase (E.C. 4.I.3.7) reacts with acetylCoA to yield citrate and to liberate free $\mathrm{CoA}$. This CoA stoichiometrically reduces added 5,5-dithiobis(2-nitrobenzoic acid) (DTNB) to yield a coloured product whose $\lambda_{\max }$ is at $412 \mathrm{~m} \mu$ (Srere, Brazil \& Gonen, 1963).

Silica cuvettes contained (in I ml. final vol.): tris- $\mathrm{HCl}$ buffer, $\mathrm{pH} 7 \cdot 8,50 \mu$ mole; ATP, $5 \mu$ mole; $\mathrm{MgCl}_{2}$, Io $\mu$ mole; $\mathrm{KHCO}_{3}$, Io $\mu$ mole; acetylCoA, $0.5 \mu$ mole; 
DTNB, O.I $\mu$ mole; citrate synthase (Boehringer), I unit; bacterial extract, 0.4 to $0.6 \mathrm{mg}$. soluble protein. The reaction was started by adding $2 \mu$ mole pyruvate to the test cuvette and the rate of increase in extinction at $4 \mathrm{I} 2 \mathrm{~m} \mu$ was measured. Assuming $\epsilon_{412}$ of reduced DTNB to be $\mathrm{I} \cdot 36 \times \mathrm{IO}^{4} \mathrm{M}^{-1} \mathrm{~cm} .^{-1}$, the specific activity of the enzyme was calculated as $\mu$ mole product $/ \mathrm{mg}$. of protein $/ \mathrm{hr}$.

(b) A malate dehydrogenase-coupled assay. Oxaloacetate produced, in the presence of excess malate dehydrogenase (E.C. I.I.I.37), oxidizes added NADH; the disappearance of $\mathrm{NADH}$ is followed at its $\lambda_{\max }$ of $340 \mathrm{~m} \mu$.

Silica cuvettes contained (in I ml. final vol.): tris- $\mathrm{HCl}$ buffer, $\mathrm{pH} 7 \cdot 8,50 \mu$ mole; ATP, $5 \mu$ mole; $\mathrm{MgCl}_{2}$, Io $\mu$ mole; $\mathrm{KHCO}_{3}$, Io $\mu$ mole; malate dehydrogenase (Boehringer), 2 units; NADH, $0 . \mathrm{I} \mu$ mole; cell extract, 0.4 to $0.6 \mathrm{mg}$. of soluble protein. The 'blank' cuvette contained the above system minus NADH. The rate of decrease in extinction at $340 \mathrm{~m} \mu$ was first followed to determine the background activity of any NADH oxidase; any increase in this rate was then measured after adding pyruvate $\left(2 \mu\right.$ mole) and acetylCoA ( $0.5 \mu$ mole) to the 'test' cuvette. Assuming $\epsilon_{340}$ of NADH to be $6.2 \times 10^{3} \mathrm{M}^{-1} \mathrm{~cm} .^{-1}$, the specific activity of the enzyme was calculated as $\mu$ mole product $/ \mathrm{mg}$. of protein $/ \mathrm{hr}$.

\section{RESULTS AND DISCUSSION}

\section{Pyruvate carboxylase in wild-type Rhodopseudomonas spheroides}

The parent, wild-type organism was grown (a) anaerobically in the light, and $(b)$ aerobically in the dark, in the defined, liquid medium containing various sources of carbon (Table I). Extracts were assayed, by the citrate synthase-coupled procedure, for their content of pyruvate carboxylase activity. Table I shows that the enzyme was always present, though at greatest specific activity in organisms grown aerobically in the dark, especially on pyruvate or in a medium containing lactate.

\section{Table I. Specific activity of pyruvate carboxylase in cell extracts of wild-type Rhodopseudomonas spheroides grown on various carbon sources}

\begin{tabular}{|c|c|c|}
\hline \multirow[b]{2}{*}{ Carbon source(s) for growth } & \multicolumn{2}{|c|}{$\begin{array}{c}\text { Specific activity of pyruvate carboxylase* } \\
(\mu \text { mole product } / \mathrm{mg} \text {. protein } / \mathrm{hr})\end{array}$} \\
\hline & $\begin{array}{l}\text { Organisms grown } \\
\text { anaerobically in } \\
\text { the light }\end{array}$ & $\begin{array}{l}\text { Organisms grown } \\
\text { aerobically in } \\
\text { the dark }\end{array}$ \\
\hline Acetate $(25 \mathrm{~mm})$ plus $\mathrm{CO}_{2} \dagger$ & 0.57 & $1 \cdot 20$ \\
\hline Glucose ( $2 \mathrm{~mm})$ & 0.92 & $1 \cdot 15$ \\
\hline Pyruvate (20 mM) & $I \cdot I 5$ & $2 \cdot 50$ \\
\hline DL-Malate (20 mM) & 0.94 & $1 \cdot 00$ \\
\hline Lactate $(20 \mathrm{mM})$ plus DL-malate ( $5 \mathrm{~mm})$ & 0.66 & $2 \cdot 10$ \\
\hline
\end{tabular}

* Assayed by the citrate synthase-coupled procedure (see Methods).

† During anaerobic/light growth, all cultures were sparged with $95 \% \mathrm{~N}_{2}: 5 \% \mathrm{CO}_{2}$; for aerobic/ dark growth on actate plus $\mathrm{CO}_{2}$, sodium bicarbonate $(6 \mathrm{~mm})$ was added immediately before inoculation.

Preincubation of the crude extract with avidin (400 units $/ \mathrm{mg}$. protein) for $6 \mathrm{~min}$. at $25^{\circ}$, completely abolished the activity of the pyruvate carboxylase. Similar preincubation with avidin plus excess biotin $(0.5 \mathrm{mg} . / \mathrm{mg}$. protein) brought about no decrease in enzyme activity.

The effect of acetylCoA on the activity of the enzyme could not be investigated 
using the citrate synthase-coupled assay method, since in this method acetylCoA is an essential reactant, so the malate dehydrogenase-coupled assay procedure was employed. To diminish interference by the 'background' activity of the NADH oxidase in the extract, the pyruvate carboxylase was partially purified at $0^{\circ}$ by precipitating nucleic acids with protamine sulphate ( $1 \mathrm{mg}$./ $10 \mathrm{mg}$. of protein) and fractionating the supernatant with ammonium sulphate. The 35 to $50 \%$ saturated ammonium sulphate precipitate was approximately 3 times purified in pyruvate carboxylase specific activity (assayed by the citrate synthase-coupled method). When assayed by the malate dehydrogenase-coupled procedure this partially purified enzyme demonstrated no activity in the absence of added acetylCoA.

It would appear from these findings that the pyruvate carboxylase of Rhodopseudomonas spheroides possesses the usual biotin requirement, and resembles the enzyme of several other bacterial species in being acetylCoA-dependent (Utter \& Scrutton, I969).

\section{Absence of phosphoenolpyruvate synthetase and of phosphoenolpyruvate carboxylase activities}

Crude extracts of wild-type Rhodopseudomonas spheroides, prepared from organisms grown $(a)$ anaerobically in the light and $(b)$ aerobically in the dark on all of the carbon sources listed in Table I, demonstrated no phosphoenolpyruvate synthetase or phosphoenolpyruvate carboxylase activities when assayed by the procedures described.

Since it was conceivable that slight activity of phosphoenolpyruvate synthetase could, in crude cell extracts, be masked by the activity of a pyruvate kinase, and because the enzyme derived from Escherichia coli в is cold sensitive (Cooper \& Kornberg, 1969), further evidence for the absence of this enzyme was sought. For this purpose wild-type $R$. spheroides was grown $(a)$ anaerobically in the light, and $(b)$ aerobically in the dark on lactate medium. The harvested organisms were washed with $5 \mathrm{~mm}$ tris- $\mathrm{HCl}+\mathrm{I} \mathrm{mM}^{-} \mathrm{MgCl}_{2}$ buffer, $\mathrm{pH} \mathrm{7 \cdot 4}$, and were resuspended in this buffer at about $20 \mathrm{mg}$. dry $\mathrm{wt} / \mathrm{ml}$. Extracts prepared by ultrasonic treatment for $3 \mathrm{~min}$. at 5 to $10^{\circ}$ were divided into two portions. One was stored and fractionated at room temperature, the other was treated similarly, but held throughout at o to $2^{\circ}$. Debris was removed from these extracts by centrifuging at $25,000 \mathrm{~g}$ for $30 \mathrm{~min}$. (instead of the usual I 5 min.) and the phosphoenolpyruvate synthetase activities assayed immediately by both procedures (see Methods). Following the precedent set by Buchanan \& Evans (1966), $80 \%$ saturated ammonium sulphate precipitates were obtained from these extracts and were similarly assayed. No phosphoenolpyruvate synthetase activity was detected in any of these fractions. On the other hand, the activity of a sample of purified phosphoenolpyruvate synthetase (prepared by Dr R. A. Cooper from $E$. coli B) was not diminished when it was reassayed after mixing with these preparations ( $4 \times 1 \mathrm{IO}^{-3} \mathrm{unit} / \mathrm{mg}$. of $R$. spheroides-derived protein).

\section{Behaviour of the pyruvate carboxylase-less mutant strain}

Extracts prepared after growth of this organism either photosynthetically or aerobically in the dark in defined liquid medium containing lactate $(20 \mathrm{~mm})$ plus malate ( $5 \mathrm{~mm}$ ) possessed no pyruvate carboxylase activity. These extracts were also devoid of phosphoenolpyruvate synthetase and phosphoenolpyruvate carboxylase activities.

This mutant differed from the parent, wild-type organism in being unable to grow 
either anaerobically in the light or aerobically in the dark on $\mathrm{CO}_{2}$ with glucose, lactate or pyruvate. Normal growth was elicited by supplementing these media with DL-malate (5 mM).

We conclude from these findings that, while Rhodopseudomonas spheroides can produce phosphoenolpyruvate from oxaloacetate (Uchida \& Kikuchi, I966), it cannot, in practice, employ its phosphoenolpyruvate carboxykinase (E.C. 4. I I . 32) to produce oxaloacetate. This means that the organism is wholly reliant upon its pyruvate carboxylase to supply the $\mathrm{C}_{4}$-dicarboxylic acids required during growth on carbon sources which only yield phosphoenolpyruvate and/or pyruvate.

\section{REFERENCES}

Buchanan, B. B. \& Evans, M. C. W. (1966). The synthesis of phosphoenolpyruvate from pyruvate and ATP by extracts of photosynthetic bacteria. Biochem. biophys. Res. Commun. 22, 484.

Buchanan, B. B., Evans, M. C. W. \& ARnon, D. I. (1967). Ferredoxin-dependent carbon assimilation in Rhodospirillum rubrum. Arch. Mikrobiol. 59, 32.

CANovas, J. L. \& Kornberg, H. L. (1969). Phosphoenolpyruvate carboxylase from Escherichia coli. In Meth. Enzym. 13, 288.

Cohen-Bazire, G., Sistrom, W. R. \& Stanier, R. Y. (1957). Kinetic studies of pigment synthesis by non-sulfur purple bacteria. J. cell. comp. Physiol. 49, 29.

COOPER, R. A. \& KORNBERG, H. L. (1967). The direct synthesis of phosphoenolpyruvate from pyruvate by Escherichia coli. Proc. Roy. Soc. Lond. B r68, 263.

COOPER, R. A. \& Kornberg, H. L. (1969). Phosphoenolpyruvate synthetase. In Meth. Enzym. 13, 309.

Evans, M. C. W., Buchanan, B. B. \& Arnon, D. I. (I966). A new ferredoxin-dependent carbon reduction cycle in a photosynthetic bacterium. Proc. natn. Acad. Sci. U.S.A. 55, 928.

LASCeLles, J. (1956). The synthesis of porphyrins and bacteriochlorophyll by cell suspensions of Rhodopseudomonas spheroides. Biochem. J. 62, 78.

Lowry, O. H., Rosebrough, N. J., FarR, A. L. \& Randall, R. J. (195I). Protein measurement with the Folin phenol reagent. J. biol. Chem. 193, 265.

SRere, P. A., BraziL, H. \& GoNen, L. (I963). The citrate condensing enzyme of pigeon breast muscle and moth flight muscle. Acta chem. scand. 17, 129.

UCHIDA, K. \& KIKUCHI, G. (1966). Phosphoenolpyruvate carboxykinase from Rhodopseudomonas spheroides and its possible role in light stimulation of gluconeogenesis. J. Biochem., Tokyo 6o, 729.

Utter, M. F. \& Scrutton, M. C. (1969). Pyruvate carboxylase. In Current Topics in Cellular Regulation. Ed. by B. L. Horecker and E. R. Stadtman, vol. I. New York: Academic Press. 